\title{
Assessment of Nutritional Status Using Mid-Upper Arm Circumference among Bengalee Preschool Children of Sagar Island, South 24 Parganas, West Bengal, India
}

\author{
Som Prasad Giri ${ }^{1}$, Sadaruddin Biswas ${ }^{2}$ and Kaushik Bose ${ }^{1}$ \\ ${ }^{1}$ Department of Anthropology, Vidyasagar University, Midnapore, West Bengal, India \\ ${ }^{2}$ Department of Anthropology and Tribal Studies, Sidho-Kanho-Birsha University, \\ Purulia, West Bengal, India
}

KEYWORDS India. Children. Preschool. Undernutrition. West Bengal

\begin{abstract}
The present cross-sectional study was conducted to evaluate mid-upper arm circumference (MUAC) based undernutrition among Bengalee preschool children. This study was undertaken among 656 (326 boys; 330 girls) 3-5 years old rural Bengalee preschool children of Sagar Block, South 24 Parganas District, West Bengal, India. The MUAC was recorded according to standard procedure and nutritional status was evaluated using the World Health Organization (1995) guidelines. Age combined sex-specific mean values of MUAC among boys and girls were $14.58( \pm 0.90) \mathrm{cm}$ and $14.48( \pm 0.85) \mathrm{cm}$ respectively. Significant sex difference was observed at the age of 4 years $(\mathrm{t}=3.88, \mathrm{P}=<0.001)$. Significant age variations were also found in mean MUAC. The overall prevalence of undernutrition was 25.61 percent. Boys (28.83\%) were more undernourished than girls (22.42\%). Prevalence of moderate undernutrition was more prevalent than severe undernutrition. Appropriate effective measures should be undertaken to reduce this undernutrition.
\end{abstract}

\section{INTRODUCTION}

The preschool age group is the foundation for lifetime health, strength and intellectual vitality (Verma and Prinja 2008) and study on assessment of nutritional status among preschool children is becoming a major priority. This age group is particularly fraught with the risk of protein-energy malnutrition (Gupta and Shukla 1992). Undernutrition is one of the greatest problems among children in developing countries like India. It is still being confronted with this problem. As in other developing nations, malnourishment is a burden on a considerable propor-

The paper is extracted from the Ph.D. thesis of Som Prasad Giri, titled 'Patterns of Growth and Nutritional status among Bengalee Pre-school Children: A Biosocial Study', which was submitted to the Vidyasagar University and was awarded on 17 January 2019. The supervisor of the thesis is Prof. Kaushik Sankar Bose of Department of Anthropology, Vidyasagar University, Midnapore-721 102, West Bengal, India

Address for correspondence:

Dr. Sadaruddin Biswas

Department of Anthropology and Tribal Studies, Sidho-Kanho-Birsha University, Purulia 7231 104, West Bengal, India

E-mail: sadarbiswas@gmail.com tion of the population, the most vulnerable being the youngest of the country (Chatterjee and Saha 2008). It has been well established that undernutrition in childhood is the leading cause of high child mortality rates in developing countries and it is highly harmful to the future of those children who survive (Pelletier 1994). Chronic undernutrition in childhood is highly determinable of slower cognitive development and serious health impairments in later life to reduce the quality of life of individuals (Scrimshaw 1996; Mandal and Bose 2009; Biswas et al. 2010).

Child growth is universally used to assess adequate nutrition, health and development of individual children, and to estimate overall nutritional status and health of populations. They have special nutritional needs because of their extensive growth and development during preschool age period (Bishnoi et al. 2004). Child undernutrition not only increases morbidity and mortality in later life but also reduces the economic development and productivity of the county. Therefore, researchers from various disciplines worldwide constantly attempt to determine the prevalence of child undernutrition using different methods.

Anthropometry is a widely accepted, inexpensive method to assess the nutritional status 
of an individual (WHO1995). Children are the future of any nation (WHO 2005). Therefore, to ensure the solid foundation and secure future of any nation, health and nutrition of children need protection. In South and South-East Asia, India ranks first in the prevalence of undernutrition (Pasricha and Biggs 2010). Moreover, the rates of undernutrition are much higher among tribal children (IIPS 2007). However, it varies in different states of India ranging between thirteen percent and fifty-five percent, representing Meghalaya and Madhya Pradesh, respectively (UNICEF 2013).

Measurement of mid-upper arm circumference (MUAC) is a fast screening method for detecting undernutrition and a good predicting indicator of risk of imminent death among early childhood. It is also a predictor of childhood mortality (Chiabi et al. 2008). The MUAC is a relatively simple measurement and compared with weight-for-height, MUAC has a sensitivity of 24.6 percent and a specificity of 94.8 percent. There are several practical and theoretical advantages of using MUAC rather than weight for height for the determination of nutritional status (Biswas et al. 2010). Moreover, in community-based studies, mid upper arm circumference (MUAC) appears to be a superior predictor of childhood undernutrition than many other anthropometric indicators (WHO1995). However, in India, reports on nutritional status using mid-upper arm circumference (MUAC) among Bengalee preschool children of Hindu castes are very scanty.

\section{Objective}

The present investigation aims to evaluate the nutritional status of the studied children using preschool age and sex-specific WHO (1995) recommended cut-off values of MUAC.

\section{METHODOLOGY}

\section{Study Area}

This present cross-sectional study was conducted at 28 Integrated Child Development Service (ICDS) scheme centres at Sagar Block of South 24 Parganas District, West Bengal, India. The study area is situated at Sagar Island (Gangasagar), Sundarban area of Kakdwip sub-division. The inhabitants are mostly of Bengalee ethnicity. This is located approximately $130 \mathrm{~km}$ away from Kolkata, the provincial capital of West Bengal. Total area of Sagar Island is 194.60 miles $\left(504 \mathrm{~km}^{2}\right)$ and it has a population of 2,06,890 according to 2011 census. This block has a population density of 1063.155 (410.49 per $\mathrm{km}^{2}$ ) per square mile. The growth rate was 20.38 percent during 2001-2011 but the decadal growth rate of South 24 Parganas is 20.89 percent whereas the decadal growth rate of this block is 17.84 percent. The area is remote and mostly inhabited by Bengalee Hindus. All preschool children (3-5 years old) living in Sagar Block are enrolled at these centres. The data was collected in several phases during November 2015 to January 2017.

\section{Subjects}

The subjects were randomly selected from 28 ICDS centres of DS-2 Gram Panchayat of Sagar block, South 24 Parganas district, West Bengal, India. A total number of 656 children (boys = 326; girls = 330) aged 3-5 years were measured. The distribution of the children is presented in Table 1. Age of the children was ascertained from the "Anganwadi" registers and subsequently confirmed from the parents of the children and recorded on a pre-structured schedule. All the studied children were Hindu by religion. Most of the parents of these children were farmers. For analysis, age was grouped into 12 months inter-

Table 1: Age and sex specific distribution of the subjects

\begin{tabular}{|c|c|c|c|c|c|c|}
\hline \multirow[t]{2}{*}{ Age group in years } & \multicolumn{2}{|c|}{ Boys $(N=326)$} & \multicolumn{2}{|c|}{ Girls $(N=330)$} & \multicolumn{2}{|c|}{ Sex combined $(N=656)$} \\
\hline & $N$ & $\%$ & $N$ & $\%$ & $N$ & $\%$ \\
\hline 3 & 119 & 36.50 & 120 & 36.36 & 239 & 36.43 \\
\hline 4 & 103 & 31.60 & 110 & 33.33 & 213 & 32.47 \\
\hline 5 & 104 & 31.90 & 100 & 30.30 & 204 & 31.10 \\
\hline Age combined & 326 & 100.00 & 330 & 100.00 & 656 & 100.00 \\
\hline
\end{tabular}


vals. Formal ethical and administrative approvals were obtained from Vidyasagar University as well as ICDS authorities prior to the commencement of the study.

\section{Anthropometric Measurement}

Anthropometric measurement of MUAC was measured by the first author (SPG) on each subject following the standard technique (Lohman et al. 1988). The MUAC was measured using a non-stretchable plastic measuring tape, to the nearest $1 \mathrm{~mm}$. The MUAC is the circumference of the left upper arm, measured at the mid-point between the tip of the shoulder and the tip of the elbow (acromion and the olecranon process). Small marks were made at the identified points. A tape was placed over those two points, and the midpoint between them was marked. Then the tape was placed around the arm in such a manner that it was touching the skin, but not compressing the soft tissues.

\section{Assessment of Nutritional Status}

There are several parameters to assess the nutritional status of the Bengalee preschool (35 years) children. Here, the researchers used appropriate and easiest technique that is, MUAC based technique. Following scheme was used: Moderate undernutrition: <2 SD, Severe undernutrition: $<3$ SD where SD refers to the age and sex-specific WHO standard deviations of mid-upper arm circumference. The age and sex-specific WHO (1995) recommended cut-off points for mid-upper arm circumference $(\mathrm{cm})$ is presented in Table 2. Age and sex-specific nutritional status of the subjects were assessed using these cut-off values.

\section{Statistical Analysis}

The data were analysed using SPSS (Version 16.00) and MS Excel software. Student's t-test was performed to see sex differences (age-specific) in mean MUAC values. One-way ANOVA (Scheffe's procedure) was done to test for age variations of MUAC.

\section{RESULTS}

The age and sex-specific distribution of mean MUAC are presented in Table 3. Age combined mean MUAC value among boys (14.58; \pm 0.90$)$ cm was greater than girls (14.48; \pm 0.85$)$. Sex combined mean values increased with age. Significant sex difference in mean MUAC was found in the age group of 4 years $(t=3.88, p<0.001)$. Significant age variations were found in mean MUAC values (Boys: $F=17.35$; $p<0.001$, Girls:

Table 2: Age and sex specific WHO (1995) recommended cut-off values for MUAC (cm)

\begin{tabular}{lcccc}
\hline Age group (in years) & \multicolumn{2}{c}{ Boys } & \multicolumn{2}{c}{ Girls } \\
\cline { 2 - 5 } & -2SD (Moderate) & -3SD (Severe) & -2SD (Moderate) & -3SD (Severe) \\
\hline 3 & 13.8 & 12.4 & 13.6 & 13.9 \\
4 & 14.1 & 12.6 & 14.1 & 12.4 \\
5 & 14.2 & 12.6 & 12.5 \\
\hline
\end{tabular}

Table 3: Age and sex specific mean values of mid-upper arm circumference

\begin{tabular}{|c|c|c|c|c|c|c|c|}
\hline \multirow[t]{3}{*}{ Age in years } & \multicolumn{4}{|c|}{ Sex } & \multirow[t]{3}{*}{ t-value } & \multicolumn{2}{|c|}{ Sex combined } \\
\hline & \multicolumn{2}{|c|}{ Boys } & \multicolumn{2}{|c|}{ Girls } & & \multirow[b]{2}{*}{ Number } & \multirow[b]{2}{*}{ Mean $(S D)$} \\
\hline & Number & Mean (SD) & Number & Mean (SD) & & & \\
\hline 3 & 119 & $14.22(0.91)$ & 120 & $14.35(0.88)$ & -1.09 & 239 & $14.28(0.89)$ \\
\hline 4 & 103 & $14.73(0.67)$ & 110 & $14.35(0.77)$ & $3.88^{* * *}$ & 213 & $14.53(0.75)$ \\
\hline 5 & 104 & $14.85(0.95)$ & 100 & $14.78(0.82)$ & 0.59 & 204 & $14.82(0.89)$ \\
\hline Age combined & 326 & $14.58(0.90)$ & 330 & $14.48(0.85)$ & 1.56 & 656 & $14.53(0.87)$ \\
\hline $\begin{array}{l}\text { F- value } \\
\text { Note: Significa }\end{array}$ & $17.35^{* * *}$ & $\begin{array}{l}9.52^{* * *} \\
0<0.001\end{array}$ & & $21.72^{* * *}$ & & & \\
\hline
\end{tabular}


Table 4: Age and sex specific nutritional status among the studied preschool children based on MUAC

\begin{tabular}{|c|c|c|c|c|c|c|c|c|c|}
\hline \multirow[t]{3}{*}{ Age in years } & \multicolumn{8}{|c|}{ Sex } & \multirow{3}{*}{$\begin{array}{c}\text { Sex } \\
\text { combined } \\
\text { under- } \\
\text { nutrition }\end{array}$} \\
\hline & \multicolumn{4}{|c|}{ Boys } & \multicolumn{3}{|c|}{ Girls } & \multirow[b]{2}{*}{$\begin{array}{c}\text { Normal } \\
(\%)\end{array}$} & \\
\hline & $\begin{array}{c}\text { Moderate } \\
(\%)\end{array}$ & $\begin{array}{l}\text { Severe } \\
(\%)\end{array}$ & $\begin{array}{c}\text { Overall } \\
(\%)\end{array}$ & $\begin{array}{c}\text { Normal } \\
(\%)\end{array}$ & $\begin{array}{c}\text { Moderate } \\
(\%)\end{array}$ & $\begin{array}{l}\text { Severe } \\
(\%)\end{array}$ & $\begin{array}{l}\text { Overall } \\
(\%)\end{array}$ & & \\
\hline \multirow[t]{2}{*}{3} & 42 & 2 & 44 & 75 & 21 & - & 21 & 99 & 65 \\
\hline & 35.29 & 1.68 & 36.97 & 63.03 & 17.5 & & 17.5 & 82.5 & 27.2 \\
\hline \multirow[t]{2}{*}{4} & 21 & - & 21 & 82 & 33 & - & 33 & 77 & 54 \\
\hline & 20.39 & & 20.39 & 79.61 & 30 & & 30 & 70 & 25.35 \\
\hline \multirow[t]{2}{*}{5} & 29 & - & 29 & 75 & 20 & - & 20 & 80 & 49 \\
\hline & 27.88 & & 27.88 & 72.12 & 20 & & 20 & 80 & 24.02 \\
\hline \multirow[t]{2}{*}{ Age combined } & d 92 & 2 & & 232 & 74 & - & 74 & 256 & 168 \\
\hline & 28.22 & 0.61 & 28.83 & 71.17 & 22.42 & & 22.42 & 77.58 & 25.61 \\
\hline
\end{tabular}

$\mathrm{F}=9.52 ; \mathrm{p}<0.001$ and sex combined $\mathrm{F}=21.72 ; \mathrm{p}$ $<0.001)$.

Age and sex-specific prevalence (\%) of undernutrition among the studied Bengalee preschool children based on MUAC is presented in Table 4. The overall rate of undernutrition was 25.61 percent. Age-specific and sex combined highest rate of undernutrition was noticed at the age of 3 years (27.20\%). Age combined rate of undernutrition among boys and girls were 28.83 percent and 22.42 percent, respectively. In case of age and sex-specific, the highest number of moderate undernourished boys (35.29\%) and girls (30\%) were found at the age of 3 and 4 years, respectively. The age and sex-specific rate of severe undernutrition were noticed among boys $(1.68 \%)$ only at the age of 3 years. The above result depicts that boys were more undernourished than their counterpart.

\section{DISCUSSION}

It has been documented that undernutrition has become a major public health problem in the developing world. Therefore, the United Nations adopted child undernutrition as one of The Eight Millennium Development Goals (Todaro and Smith 2005) in 2000. Measurement of MUAC is a quick and reliable method for screening children to identify those who are seriously malnourished (Biswas et al. 2010). Several studies have been used MUAC to identify children as having moderate and severe acute malnutrition for its simplicity (Biswas et al. 2010; Mandal et al. 2009; Bisai 2010).

The researchers' results revealed that overall rate of undernutrition was 25.61 percent and these rates were slightly higher among the boys (28.83\%) than girls (22.42\%). The prevalence of undernutrition among the Bengalee preschool children of the present study was much lower than (Table 5) those reported MUAC based study among the Bengalee preschool children (77.8\%) of North 24 Parganas (Bisai 2010) and Hooghly district (64.5\%) of West Bengal (Mandal and Bose 2009). The rate of undernutrition among the preschool children of the present study was higher than the reported MUAC

Table 5: Comparison of the overall prevalence (\%) of undernutrition with other studies

\begin{tabular}{lccc}
\hline Studied area (District/State) & $\begin{array}{c}\text { Number of children } \\
\text { studied }\end{array}$ & $\begin{array}{c}\text { Prevalence } \\
(\%)\end{array}$ & References \\
\hline (A) Punjab & 6531 & 38.52 & Kaur et al. 2005 \\
(B) Khurda and Cuttack, Orissa & 101 & 35.6 & Chakraborty et al. 2006 \\
(C) Cuttack, Orissa & 292 & 29.1 & Mishra and Mishra 2007 \\
(D) Kolkata, West Bengal & 21 & 28.6 & Chatterjee and Saha 2008 \\
(E) Yaounde, Cameroon & - & 21.6 & Chiabi et al. 2008 \\
(F) Hooghly, West Bengal & 894 & 64.5 & Mandal and Bose 2009 \\
(G) Nadia, West Bengal & 2016 & 35.11 & Biswas et al. 2010 \\
(H) North 24 Parganas, West Bengal & 899 & 77.8 & Bisai 2010 \\
(I) Midnapore Town, West Midnapore & 1060 & 18.96 & Maiti et al. 2012 \\
(J) Sagar Block, South 24 Parganas, West Bengal & 656 & 25.61 & Present Study \\
\hline
\end{tabular}


based undernutrition status of 1-3 years age group of Midnapore (18.96\%) town children (Maiti et al. 2012). The rate of undernutrition among the rural Bengalee children of 3-5 years old of Chapra block of Nadia district (35.11\%) was (Biswas et al. 2010) higher than the present study. The studies conducted in immunization clinic of Kolkata (Chatterjee and Saha 2008), and Cuttack Orissa (Mishra and Mishra 2007) showed that the rate of undernutrition (28.6\% and $29.1 \%$, respectively) were comparatively slightly higher than the present study. Kaur et al. (2005) (38.52\%) and Chakraborty et al. (2006) (35.6\%) showed that MUAC based prevalence rate of undernutrition was comparatively higher than the present study. Chiabi et al. (2008) observed that slightly lower rate $(21.6 \%)$ of undernutrition compared to the present study (Table 5). However, the present study showed that the low rate of undernutrition than other most of the MUAC based study. So it can be said that the nutritional status of studied preschool children was not so serious than the others reference study. But considering stunting, underweight, wasting and thinness among the same population, the high prevalence of undernutrition was also noticed (Giri et al. 2017a; Giri et al. 2017b).

It was noticed that age plays a significant role in MUAC and weight for height discrepancies, as it is associated with food insecurity (Young and Jaspers 2009). Among the young children wasting is indicative of disease together with poor feeding practices (Dukhi et al. 2017). It was also observed that during a period of food insecurity, older children are likely to experience more acute malnutrition (Bern and Nathanail 1995) than younger ones.

\section{CONCLUSION}

Moreover, it has been reported that there is little improvement in child undernutrition for the last decade and the government of India was going to restructure its program for nutritional intervention for children up to the age of 6 years.

\section{RECOMMENDATIONS}

Nutritional status of the studied children is not satisfactory and it is further suggested that the use of MUAC alone can possibly mask malnutrition problems in children and therefore create inaccurate findings of regional or national food insecurity.

\section{LIMITATION}

However, it should be mentioned here that a major limitation of the present study is that detailed relationships between various socio economic factors and morbidity, mortality with childhood undernutrition, based on MUAC, are not being reported.

\section{ACKNOWLEDGEMENTS}

The researchers would like to thank all the concerned ICDS staff and also parents of the subjects for their assistance. They owe their thanks to the children who participated in this study. Special thanks are due to the ICDS authority of Sagar Block, South 24 Parganas.

\section{REFERENCES}

Bern C, Nathanail L 1995. Is mid-upper-arm circumference a useful tool for screening in emergency settings? Lancet, 345: 631-633.

Bisai S 2010. Nutrition status based on mid-upper arm circumference among urban, poor pre-school children in North 24 Parganas, West Bengal, India. Serbian J Experi Clin Research, 114: 141-145.

Bishnoi P, Sehgal S, Kwatra A 2004. Anthropometric measurements of preschool children as effected by socio-economic factors. Asia Pacific Journal of Clinical Nutrition, 13(Suppl.): S132.

Biswas S, Bose K, Mukhopadhyay A, Bhadra M 2010. Mid-upper arm circumference based undernutrition among Bengalee children of Chapra, West Bengal, India. Iran J Pedia, 20(1): 63-68.

Chatterjee S, Saha S 2008. A study on knowledge and practice of mothers regarding infant feeding and nutritional status of under five children attending immunization clinic of a medical college. Inter $J$ Nutri Wellness, 5: 1.

Chiabi Andreas C, Tchokoteu PF, Takou V, Fru FS, Tchouine F 2008. Anthropometric measurements of children attending a vaccination clinic in Yaounde, Cameroon. Afri Health Sci, 8(3): 174-179.

Dukhi N, Sartorius B, Taylor M 2017. Mid-upper arm circumference (MUAC) performance versus weight for height in South African children (0-59 months) with acute malnutrition. South Afri J Clin Nutri, 30(2): 49-54.

Giri SM, Biswas S, Bose K 2017a. Prevalence of undernutrition among Bengalee preschool children of Sundarban, South 24 Parganas, West Bengal, India. Hum Biol Revie, 6(4): 284-300.

Giri SM, Biswas S, Bose K 2017b. Very high prevalence of thinness among rural Bengalee preschool children of integrated child development service (ICDS) scheme of Sagar Island, South 24 Parganas, West Bengal, India. Anthro Open J, 2(2): 54-60.

Gupta VM, Shukla KK 1992. Epidemiological correlates of protein energy malnutrition in pre-school chil- 
dren. Indian Journal of Preventive and Social Medicine, 23: 26-32.

IIPS 2007. National Family Health Survey (NFHS-3). Mumbai, India: International Institute for Population Sciences (IIPS), Macro International.

Kaur G, Kang HS, Singal P, Singh S 2005. Nutritional status: Anthropometric perspective of preschool children. Anthropologist, 7(2): 99-103.

Lohman TG, Roche AF, Martorell R 1988. Anthropometric Standardization Reference Manual. Chicago, IL: Human Kinetics Books.

Maiti S, Ali KM, De D, Bera TK, Ghosh D, Paul S 2012. Evaluation of nutritional status by mid-upper arm circumference amongst affluent children. $J \mathrm{Ne}$ pal Paedia Socie, 32(2): 113-116.

Mandal GC, Bose K 2009. Assessment of undernutrition by mid-upper arm circumference among preschool children of Arambag, Hooghly District, West Bengal, India: An observational study. Inter J Pedia Neonat, 11: 1.

Mishra BK, Mishra S 2007. Nutritional anthropometry and preschool child feeding practices in working mothers of central Orissa. Stud on Home and Comm Sci, 1(2): 139144.

Pasricha SR, Biggs BN 2010. Undernutrition among children in South and South-East Asia. J Paedia Child Health, 46: 497-503.

Pelletier DL 1994. The relationship between child anthropometry and mortality in developing countries: Implications for policy, programs and future research. J Nutri, 124(10suppl): 2047S 2081S.
Scrimshaw NS 1996. Nutrition and health from womb to tomb. Nutri Today, 31: 5567.

The Times of India 2008. Government to Hike Spend in Child Nutrition Plan. The Times of India, New Delhi, June 24, P. 8. From <www. indiaenvironmentportal. org.in/content/govt-hike-spend-child-nutrition-plan> (Retrieved on 10 March 2018).

Todaro MP, Smith SC 2005. Economic Development. $9^{\text {th }}$ Edition. Boston: Pearson-Anderson Wesley.

UNICEF India 2013. From <http: //www.unicef.org/ india/children_2356.htm> (Retrieved on 27 December 2017).

Verma R, Prinja S 2008. Assessment of nutritional status and dietary intake of pre-school children in an urban pocket. Inter J Epidemiol, 6: 1.

World Health Organization (WHO) 1995. Physical Status: The Use and Interpretation of Anthropometry: Technical Report. Report No.854. Geneva: World Health Organization.

World Health Organization (WHO) 2005. The World Health Report: Make Every Mother and Child Count. Geneva: World Health Organization.

Young H, Jaspers S 2009. Review of Nutrition and Mortality Indicators for the Integrated Food Security Phase Classification (IPC). From <https: // www.odi.org/sites/odi.org.uk/files/odi-assets/publications-opinion-files/5636.pdf> (Retrieved on 30 December 2017).

Paper received for publication on April 2018

Paper accepted for publication on February 2019 